\title{
Antimicrobial activity of Pityrocarpa monilifomis leaves and its capacity to enhance the activity of four antibiotics against Staphylococcus aureus strains
}

\author{
Juliette Ferreira Vieira da Silva ${ }^{1}$, Luís Cláudio Nascimento da Silva ${ }^{2}$, Isabel Renata de \\ Souza Arruda ${ }^{1}$, Alexandre Gomes da Silva ${ }^{1}$, Alexandre José Macedo ${ }^{3}$, Janete Magali de \\ Araújo $^{4}$, Maria Tereza dos Santos Correia ${ }^{2}$ and Márcia Vanusa da Silva ${ }^{1 *}$ \\ ${ }^{1}$ Laboratório de Produtos Naturais, Departamento de Bioquímica, Centro de Ciências Biológicas, Universidade Federal \\ de Pernambuco. Av. Prof. Moraes Rego, s/n, CEP 50.670-420. Recife, PE, Brazil. \\ ${ }^{2}$ Laboratório de Glicoproteínas, Departamento de Bioquímica, Centro de Ciências Biológicas, \\ Universidade Federal de Pernambuco, Av. Prof. Moraes Rego, s/n, CEP 50.670-420. Recife, Brazil. \\ ${ }^{3}$ Universidade Federal do Rio Grande do Sul, Faculdade de Farmácia and Centro de \\ Biotecnologia, Av. Ipiranga, 2752 Porto Alegre, RS, CEP 90610-000, Brazil. \\ ${ }^{4}$ Laboratório de Genética de Microrganismos, Departamento de Antibióticos, Centro de Ciências Biológicas, \\ Universidade Federal de Pernambuco. Av. Prof. Moraes Rego, s/n, CEP 50.670-420. Recife, PE, Brazil.
}

Accepted 12 July, 2013

\begin{abstract}
This work evaluated the antimicrobial activity of Pityrocarpa monilifomis leaves and the effects of extract and two active fractions in combination with four antibiotics against Staphylococcus aureus strains. The extract only inhibited Gram positive bacteria, whereas the fractions also showed activity against Gram negative organism. Only n-butanol fraction showed synergistic/additive effects with all tested drug. Certainly as a consequence of saponin presence (it has a great hemolytic capacity). This study showed at first time the antimicrobial activity extract/fractions of leaves from $P$. moniliformis and their capacity to enhance the anti-S. aureus activity of some protein inhibitors drugs.
\end{abstract}

Key words: Caatinga, saponins, synergism, Pityrocarpa moniliformis, antimicrobial.

\section{INTRODUCTION}

Pityrocarpa monilifomis is a valuable source of bioactive compounds with great diversity in the structure and physicochemical properties. The history of the discovery and use of drugs derived from plants date from several centuries. The oldest written evidence of the use of plants for drugs preparation has been found approximately 5000 years old, and it also has been described by Shen-Nung (2838-2698 BC) (Kelly, 2009; Petrovska, 2012; Lien, Lien and Adms, 2013). The high potential of plants is due to their great diversity in the structure and physicochemical properties (Newman and Cragg, 2012).

In recent years, resistance of pathogenic micro- organisms to multiple drugs has increased due to the indiscriminate use of antimicrobials, commonly marketed and used in the treatment of infectious diseases (Paphitou, 2013; Toutain and Bousquet-Melou, 2013). Due to the increasing microbial resistance to drugs, the search for new antimicrobial agents from plants is intense (Radulovic et al., 2013), mainly because of the lower search costs, probable less risk of side effects and a great potential of synergistic effect (Saleem et al., 2010; Vuuren and Viljoen, 2011).

The Caatinga is a unique biome of Brazil and this region is marked by an accentuated dryness (rainfall is 
usually less than $600 \mathrm{~mm} /$ year). The Caatinga is also named as Semi-arid region and occupies a large portion of Brazil's Northeast, comprising several plant species (Albuquerque et al., 2012). As a result of the environmental conditions to which they are exposed, the Caatinga plants have developed interesting chemical features and they have been described as excellent weapons against microorganisms (Almeida et al., 2012; Silva et al., 2012; Da Silva et al., 2012; Tretin et al., 2013). Pityrocarpa moniliformis (=Piptadenia moniliformis) Benth (Leguminosae - Mimosoideae) is a woody plant in Northeastern Brazil popularly known as angico-de-bezerro, which also occurs in dry forests in the region of Sucre (Venezuela). Our group has been the first to show that this plant is a source of active compounds with antimicrobial, anti-bacterial biofilms and antioxidant activities (Da Silva et al., 2011, 2012; Trentin et al., 2011). This study aimed to evaluate: (1) the antimicrobial activity of the hydroalcoholic crude extract of leaves and its fractions, (2) the synergetic potential with antibiotics that act on protein synthesis, and (3) test the hemolytic activity of extract and fractions that showed better results.

\section{MATERIALS AND METHODS}

\section{Plant collection and plant storage}

Leaves of $P$. moniliformis were collected in Parque Nacional do Catimbau, Pernambuco, Brazil, Northeastern Brazil, in September 2010. Botanical identification was made by staff of the Herbarium of Instituto de Pesquisa Agronômica de Pernambuco (IPA), Brazil, and voucher specimens were deposited in the herbarium (IPA 84.048). Leaves were dried at room temperature. The dried plants were milled to a fine powder in a Macsalab mill (Model 200 LAB), Eriez $^{\circledR}$, Bramley, and stored at room temperature in closed containers in the dark until used.

\section{Preparation of the crude hydroalcoholic extract}

P. moniliformis leaves were dried at room temperature for 7 days, ground into a fine powder and used for extraction. The powder $(20$ g) was mixed with $50 \mathrm{ml}$ ethanol:water (7:3) and submitted to agitation for 15 hours. Then the extracts were filtered and the powder residue was mixed again with $50 \mathrm{ml}$ ethanol-water and the entire extraction process was repeated. The supernatants collected were mixed in a round bottom flask and concentrated at $45^{\circ} \mathrm{C}$. The residue was dissolved in DMSO (dimethyl sulfoxide) and kept at $20^{\circ} \mathrm{C}$ until use.

\section{Phytochemical analysis}

The phytochemical tests to detect the presence of tannins, flavonoids, anthocyanins, saponins, coumarins, quinones, anthraquinones, reducers compounds and alkaloids were performed according to the method described by Kokate (1994) and Harborne (1998).

\section{Fractionation of the hydroalcoholic extract}

The hydroalcoholic extract was dissolved in water, producing a solution that was submitted to liquid-liquid partitions successively with cyclohexane, ethyl acetate and $\mathrm{n}$-butanol. The solutions produced were dried in anhydrous $\mathrm{Na}_{2} \mathrm{SO}_{4}$ and submitted to filtration under reduced pressure. Thereafter, the solvents were evaporated under reduced pressure in a rotary evaporator oven at $60^{\circ} \mathrm{C}$, producing hexane, ethyl acetate, n-butanol soluble and $n$ butanol non-soluble phases. The residues obtained were kept at $20^{\circ} \mathrm{C}$ for future use.

\section{Microbial strains}

The antimicrobial activity of $P$. moniliformis leaves extract and its fractions were tested against the following microorganisms: Staphylococcus aureus (UFPEDA02), Micrococcus luteus (UFPEDA100), Escherichia coli (UFPEDA 224), Klebsiella pneumaniae (UFPEDA 396), Salmonella enteritidis (UFPEDA 414), Pseudomonas aeruginosa (UFPEDA416) and some $S$. aureus recently isolated strains (UFPEDA 660, UFPEDA 663, UFPEDA 676, UFPEDA 687, UFPEDA 712, UFPEDA 733) (Table 1). All strains were provided by Departamento de Antibióticos, Universidade Federal de Pernambuco (UFPEDA) and maintained in Nutrient Agar (NA) and stored at $4^{\circ} \mathrm{C}$.

\section{Minimum inhibitory concentration (MIC) and the minimum bactericidal concentration (MBC)}

MIC was determined by the microdilution method (CLSI, 2011). A twofold serial dilution of the extract/fractions was prepared in Mueller Hinton Broth (MHB) and $100 \mu \mathrm{l}$ (approximately $1.5 \times 10^{8}$ $\mathrm{CFU} / \mathrm{ml}$ ) of bacteria suspension was added. The samples were incubated for $24 \mathrm{~h}$ at $37^{\circ} \mathrm{C}$. Resazurin solution $(0.01 \%)$ was used as an indicator by color change visualization: any color changes from purple to pink were recorded as bacterial growth. The lowest concentration at which no color change occurred was taken as the MIC. Afterwards, cultures were seeded in MHA medium and incubated for $24 \mathrm{~h}$ at $37^{\circ} \mathrm{C}$ to determine the $\mathrm{MBC}$ which corresponds to the minimum concentration of extract/fractions that eliminated the bacteria.

\section{Evaluation of combinatory effects of extract and drugs}

The combinatory effects of extract/fraction and drug were tested by Checkerboard method (Vuuren and Viljoen, 2011). The drugs tested were: chloramphenicol (chlor), erythromycin (eryth), streptomycin (strep), and tetracycline (tetra). To this test, sample solutions $(100 \mathrm{mg} / \mathrm{ml})$ and drug $(1 \mathrm{mg} / \mathrm{ml})$ were mixed at $1: 1 \mathrm{ratio}$, in a final volume $20 \mu \mathrm{l}$, and serially diluted. Interaction was assessed algebraically by determining the Fractional inhibitory concentration index ( $\Sigma F I C)$, according to the following equation:

¿FIC: $(\mathrm{MICE}+\mathrm{D} / \mathrm{MICE})+(\mathrm{MICD}+\mathrm{E} / \mathrm{MICD})$

where MIC: minimal inhibitory concentration; MICE+D: minimal inhibitory concentration of extract/fraction in combination with drug; $\mathrm{MICD}+\mathrm{E}$ : minimal inhibitory concentration of drug in combination with extract/fraction.

Data interpretation: synergism $(\Sigma \mathrm{FIC} \leq 0.5)$, additive $(0.5<\Sigma \mathrm{FIC} \leq$ $1)$; noninteractive $(1<\Sigma F I C<4)$; antagonist $(\Sigma F I C \geq 4)$.

\section{In vitro hemolytic assay}

Blood (5 to $10 \mathrm{ml}$ ) was obtained from healthy non-smoking volunteers by venipuncture, after written informed consent was obtained. Human erythrocytes from citrated blood were immediately 
Table 1. Antimicrobial activity of $P$. moniliformis leaves hydroalcoholic extract and its fractions.

\begin{tabular}{|c|c|c|c|c|c|c|c|c|c|c|c|}
\hline \multirow{2}{*}{\multicolumn{2}{|c|}{$\begin{array}{l}\text { Microorganism } \\
\text { UFPEDA }\end{array}$}} & \multicolumn{2}{|c|}{$\begin{array}{l}\text { Hydroalcoholic } \\
\text { crude extract }\end{array}$} & \multicolumn{2}{|c|}{$\begin{array}{l}\text { Ethyl acetate } \\
\text { fraction }^{1}\end{array}$} & \multicolumn{2}{|c|}{$\begin{array}{l}\text { Cyclohexane } \\
\text { fraction }\end{array}$} & \multicolumn{2}{|c|}{$\begin{array}{l}\text { n-Butanol } \\
\text { fraction }\end{array}$} & \multicolumn{2}{|c|}{ Aqueous fraction } \\
\hline & & MIC $^{2}$ & $\mathrm{MBC}^{2}$ & MIC & MBC & MIC & MBC & MIC & MBC & MIC & MBC \\
\hline 02 & S. aureus & 1.56 & 6.25 & 3.12 & 6.25 & 3.12 & 12.5 & 25 & 12.5 & 25 & 25 \\
\hline 100 & M. luteus & 0.39 & 1.56 & 6.25 & $>25$ & 6.25 & $>25$ & 6.25 & $>25$ & 12.5 & $>25$ \\
\hline 224 & E. coli & $N / A^{3}$ & $N / A$ & $\mathrm{~N} / \mathrm{A}$ & $\mathrm{N} / \mathrm{A}$ & $\mathrm{N} / \mathrm{A}$ & $\mathrm{N} / \mathrm{A}$ & $\mathrm{N} / \mathrm{A}$ & $\mathrm{N} / \mathrm{A}$ & $\mathrm{N} / \mathrm{A}$ & $N / A$ \\
\hline 396 & K. pneumoniae & $N / A$ & $N / A$ & 12.5 & $>25$ & 12.5 & $>25$ & 12.5 & $>25$ & 25 & 25 \\
\hline 414 & S. Enteretidis & $\mathrm{N} / \mathrm{A}$ & $\mathrm{N} / \mathrm{A}$ & 6.25 & $>25$ & 6.25 & $>25$ & 6.25 & $>25$ & 6.25 & 12.5 \\
\hline 416 & $P$. aeroginosa & $N / A$ & $N / A$ & 6.25 & $>25$ & 6.25 & $>25$ & 6.25 & $>25$ & 6.25 & 25 \\
\hline 660 & S. aureus ${ }^{4}$ & 1.56 & 12.5 & 1.56 & 3.13 & 6.25 & 6.25 & 3.16 & 25 & 3.16 & 12.5 \\
\hline 663 & S. aureus ${ }^{4}$ & 1.56 & 1.56 & 1.56 & 12.5 & 3.16 & $>25$ & 1.56 & $>25$ & $>25$ & $>25$ \\
\hline 676 & S. aureus ${ }^{4}$ & 3.16 & 12.5 & 3.16 & 12.5 & 3.16 & 12.5 & 3.16 & 25 & 25 & 25 \\
\hline 687 & S. aureus ${ }^{4}$ & 3.16 & 12.5 & $>25$ & $>25$ & 12.5 & 12.5 & 3.25 & 3.25 & $>25$ & $>25$ \\
\hline 712 & S. aureus ${ }^{4}$ & 3.16 & $>25$ & 3.16 & $>25$ & 3.16 & $>25$ & 6.25 & $>25$ & 6.25 & $>25$ \\
\hline 733 & S. aureus ${ }^{4}$ & 0.78 & 1.56 & 0.78 & 3.16 & 12.5 & 12.5 & 3.16 & $>25$ & 0.78 & 6.25 \\
\hline
\end{tabular}

${ }^{1}$ Crude hydroalcholic extract was dissolved in water and were submitted to liquid-liquid partitions successively with cyclohexane, ethyl acetate and $\mathrm{n}$ butanol. The solvents were evaporated and the remaining aqueous fraction was lyophilized. ${ }^{2} \mathrm{MIC}$ and $\mathrm{MMC}$ of the samples were expressed in mg/ml (CLSI, 2011). ${ }^{3} \mathrm{~N} / \mathrm{A}$ : No activity. ${ }^{4}$ Source of $S$. aureus strains: vaginal discharge, catheter tip, prosthesis secretion, ocular discharge, wound secretion transplant, bone fragment (respectively).

isolated by centrifugation at $1500 \mathrm{rpm}$ for $10 \mathrm{~min}$ at $4^{\circ} \mathrm{C}$. After removal of plasma and buffy coat, the erythrocytes were washed three times with phosphate-buffered saline (PBS; $\mathrm{pH} 7.4$ ) and then resuspended using the same buffer and a $1 \%$ erythrocyte suspension was prepared. The hemolytic activity of the crude extract was tested under in vitro conditions. Each tube received 1.1 $\mathrm{ml}$ of erythrocyte suspension and $0.4 \mathrm{ml}$ of extract of various concentrations (50 to $500 \mu \mathrm{g} / \mathrm{ml}$ ) were added. The negative control was only solvent and the positive control received $0.4 \mathrm{ml}$ of Quillaja species saponin $(0.0025 \%)$. After $60-\mathrm{min}$ incubation at room temperature, cells were centrifuged and the supernatant was used to measure the absorbance of the liberated hemoglobin at $540 \mathrm{~nm}$. The average value was calculated from triplicate assays. The hemolytic activity was expressed in relation to ascorbic acid and calculated by the following formula (Oliveira et al., 2012):

Hemolytic activity $(\%)=($ As- Ab) $\times 100 /(A c-A b)$

where $A_{c}$ was the absorbance of the control (blank, without extract), $A_{s}$ was the absorbance in the presence of the extract and Ac was the absorbance of saponin solution.

\section{Statistical analysis}

Each experiment was performed in triplicate and results are expressed as the mean \pm standard deviation (SD). Statistical analysis was performed by Student's t-test. Differences were considered significant at $p<0.05$.

\section{RESULTS AND DISCUSSION}

Several studies have been demonstrated that Caatinga plants are a rich source of biotechnology compounds, in special with remarkable antimicrobial activity (Da Silva et al., 2012; Silva et al., 2012; Jandú et al., 2013). The preliminary antimicrobial activity of extract and fractions of $P$. moniliformis are showed in Table 1 . The crude hydroalcoholic extract only inhibited Gram positive bacteria. The MIC and MBC were 1.56 and $6.25 \mathrm{mg} / \mathrm{ml}$ to $S$. aureus and 0.39 and $1.56 \mathrm{mg} / \mathrm{ml}$ to $M$. luteus. The fractions of this extract showed activity against all tested microorganism, except to E. coli. The MIC values against $S$. aureus were $3.12 \mathrm{mg} / \mathrm{ml}$ to ethyl acetate and cyclohexane, and $\mathrm{n}$-butanol and $25 \mathrm{mg} / \mathrm{ml}$ to aqueous fractions. To M. luteus, the MIC values were $6.25 \mathrm{mg} / \mathrm{ml}$ (ethyl acetate, cyclohexane and $n$-butanol fractions) and $25 \mathrm{mg} / \mathrm{ml}$ to aqueous fraction. All fractions had the same MIC value against $P$. aeruginosa of $6.25 \mathrm{mg} / \mathrm{ml}$. To $K$. pneumoniae and $S$. enteretidis inhibitory concentrations were $12.5 \mathrm{mg} / \mathrm{ml}$ (ethyl acetate, cyclohexane and $\mathrm{n}$ butanol fractions) and $25 \mathrm{mg} / \mathrm{ml}$ (aqueous fraction). According to $\mathrm{MBC} / \mathrm{MIC}$ ratio all extract and fractions may be classified as bactericidal agents $(\mathrm{MBC} / \mathrm{MIC} \leq 4)$ (Gatsing et al., 2006).

The samples were also checked against six $S$. aureus strains recently isolated from human infections, because of the anti-S. aureus effectiveness (Table 1). S. aureus is an opportunistic bacteria well adapted to humans, which causes several hospital and community acquired infections. It can live as a commensal, but provided a suitable opportunity can initiate severe infection at various body sites due to the production of a large number of virulence factors and its ability to develop survival strategies, despite the availability of effective antimicrobial agents (Shimada et al., 2010; Price et al., 2012). In this context, the search for new effective anti-S. aureus compounds is extremely important. The MIC values ranged from 0.78 to $3.16 \mathrm{mg} / \mathrm{ml}$ to hydroalcoholic 
Table 2. Combinatory effects of different drugs and extract/fractions against $S$. aureus strains.

\begin{tabular}{lcccc}
\hline Drug & Strain & $\begin{array}{c}\text { FIC } \\
\text { (Extract/Drug) }\end{array}$ & $\begin{array}{c}\text { FIC } \\
\text { (Cyclohexane fraction/Drug) }\end{array}$ & $\begin{array}{c}\text { FIC } \\
\text { (Butanol fraction/Drug) }\end{array}$ \\
\hline \multirow{3}{*}{ Chloramphenicol } & 02 & 0.5 & 0.5 & 0.5 \\
& 687 & 1.0 & 4.0 & 1.0 \\
& 733 & 2.1 & 8.4 & 0.9 \\
Erythromycin & & & & \\
& 02 & 0.5 & 0.5 & 0.5 \\
& 687 & 0.5 & 0.5 & 0.5 \\
& 733 & 1.0 & 1.0 & 1.0 \\
Streptomycin & & & & 0.6 \\
& 02 & 1.2 & 0.5 & 0.6 \\
& 687 & 2.4 & 1.2 & 1.0 \\
Tetracycline & 733 & 2.5 & 0.7 & 0.5 \\
& & & & 0.5 \\
& 02 & 0.5 & 1.0 & 0.5 \\
\hline
\end{tabular}

Table 3. Phytochemical analysis of Pityrocarpa moniliformis leaves.

\begin{tabular}{ll}
\hline Positive & Negative \\
\hline Saponins & Alkaloids \\
Flavonoids & Carbohydrates \\
Triterpenes & Cinnamic acid derivatives \\
Gallics tannins & Caffeine \\
\hline
\end{tabular}

extract and cyclohexane fraction; 1.56 to $6.25 \mathrm{mg} / \mathrm{ml}$ to $\mathrm{n}$ butanol fraction; 3.13 to $12.5 \mathrm{mg} / \mathrm{ml}$ to ethyl acetate fraction; and 0.78 to $25 \mathrm{mg} / \mathrm{ml}$ to aqueous fraction. Both aqueous and cyclohexane fractions did not inhibit the 687 strain.

Given the high capacity of $S$. aureus to developing drug resistance, which contributes to clinical infections, is also extremely important to find news alternative substances that can enhance the activity of drug, and have been reported by various studies (Agboke et al., 2011; Chung et al., 2011). The P. moniliformis leaves hydroalcoholic extract and two of its fractions (cyclohexanic and butanolic fractions) were evaluated to their capacity to enhance the anti-S. aureus of standard antibiotics by determination of the Fractional Inhibitory Concentration indices $(\Sigma F I C)$. The results showed that the combinatory effects were strain-dependent (Table 2). The crude extract showed synergetic or addictive effect with tetracycline against all strains whiles the cyclohexane fraction showed with tetracycline and erythromycin. On other hand, the butanolic fraction showed synergetic or addictive effect with all tested drug, which may be explained by saponin presence, which can cause membrane permeabilization (Hassan et al., 2010).

In the hemolytic assay, the hydroalcoholic extract and butanolic fraction had the lowest $\mathrm{HC}_{50}$ (the concentration needed for $50 \%$ of hemolysis) (1.91 and $3.92 \mathrm{mg} / \mathrm{ml}$ ). This effect may be attributed by saponin presence in crude extract (Table 3), which is known as hemolytic agent (Hassan et al., 2010) and is frequently soluble in ethanol and butanol (Levy et al., 1989). The cyclohexanic fraction showed $\mathrm{HC}_{50}$ of $6.11 \mathrm{mg} / \mathrm{ml}$ (Figure 1). The $\mathrm{HC}_{50}$ of active anti-S. aureus fractions were higher than the MIC values.

Phytochemical analysis of $P$. moniliformis leaves revealed the presence of triterpenes, saponin, flavonoids (luteolin, proanthocyanidin), and gallics tannin. All these classes of compounds are reported as antimicrobial agents. Triterpenes are reported as antimicrobial and synergetic compounds (Chung et al., 2011). Flavonoids, soluble in ethyl acetate and n-butanol, are bacteriostatic and has multiple bacterial targets (nucleic acid synthesis, cytoplasmic membrane function or energy metabolism) (Tim and Lamb, 2005). Saponins antimicrobial activity is reported and usually is related to the aglycone part (Hassan et al., 2010). Finally, gallic tannin is able to inactivate microbial adhesins, enzymes, cell envelope transport proteins, etc (Cowan, 1999).

\section{Conclusion}

P. moniliformis leaves are an important source of substances possessing antimicrobial activity, including against $S$. aureus clinical isolates. The crude extract, 


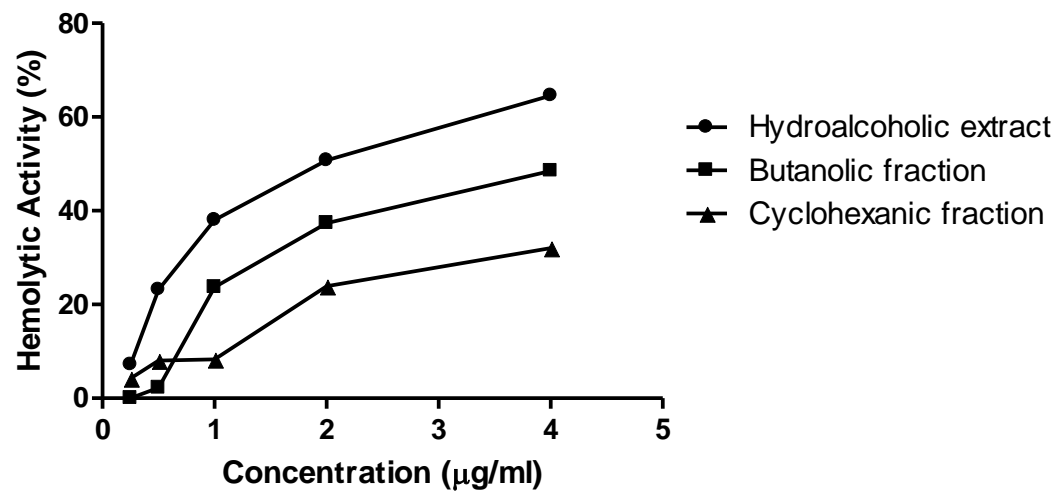

Figure 1. Hemolytic activity of $P$. moniliformis leaves hydroalcoholic extract and its fractions.

cyclohexanic and butanolic fractions are able to enhance the activity of erythromycin and tetracycline. Butanolic fraction showed synergetic effect with all tested antibiotic. The purification and structural characterization of compounds from active fractions are being performed by our group.

\section{ACKNOWLEDGEMENTS}

The authors wish to thank the Brazilian agencies (Conselho Nacional de Desenvolvimento Científico e Tecnológico, Coordenação de Aperfeiçoamento de Pessoal de Nível Superior and Fundação de Amparo à Ciência e Tecnologia do Estado de Pernambuco) for the grant.

\section{REFERENCES}

Agboke A, Jackson C, Adedokun M, Momoh MA (2011). In vitro evaluation of the interaction between methanol extract of lichen (Ramalina farinacea) and tetracycline against clinical isolates of Staphylococcus aureus. Afr. J. Biotechnol. 10:2314-2318.

Albuquerque UP, Lima Araújo E, El-Deir ACA, Lima ALA, Souto A Bezerra BM, Ferraz EBN, Freire EMX, Sampaio EVB, Las-Casas FMG, Moura GJB, Pereira GA, Melo JG, Ramos MA, Rodal MJN, Schiel N, Lyra-Neves RM, Alves RRN, Azevedo-Júnior SM, Júnior WRT, Severi W (2012). Caatinga revisited: ecology and conservation of an important seasonal dry forest. Sci. World J. 2012:1-18.

Almeida CFCBR, Cabral DLV, Almeida CCBR, Amorim ELC, Araújo JM, Albuquerque UP (2012). Comparative study of the antimicrobial activity of native and exotic plants from the Caatinga and Atlantic Forest selected through an ethnobotanical survey. Pharm. Biol. 50:201-220.

Chung PY, Navaratnam P, Chung LY (2011). Synergistic antimicrobial activity between pentacyclic triterpenoids and antibiotics against Staphylococcus aureus strains. Ann. Clin. Microbiol. Antimicrob. 10:1-6.

Clinical and Laboratory Standards Institute (CLSI) (2011). "Performance standards for antimicrobial susceptibility testing (21st edn) Wayne: M100-S21", Clinical and Laboratory Standards Institute.

Cowan MM (1999). Plant products as antimicrobial agents. Clin. Microbiol. Rev. 12:564-582.
Da Silva LCN, Sandes JM, Paiva MM, Araújo JM, Figueiredo RCBQ, Silva MV, Correia MTS (2012). Anti-Staphylococcus aureus action of three Caatinga fruits evaluated by electron microscopy. Nat. Prod. Res. 2012:1-5.

Da Silva LCN, Silva-Júnior CA, Souza RM, Macedo AJ, Silva MV, Correia MTS (2011). Comparative analysis of the antioxidant and DNA protection capacities of Anadenanthera colubrina, Libidibia ferrea and Pityrocarpa moniliformis fruits. Food Chem. Toxicol. 49:2222-2228

Gatsing D, Mbah JA, Garba IH, Tane P, Djemgou P, Nji-Nkah BF (2006). An antisalmonellal agent from the leaves of Glossocalyx brevipes Benth (Monimiaceae). Pak. J. Biol. Sci. 9:84-87.

Harborne JB (1998). Phytochemical Methods, London: Chapman \& Hall pp. 60-66.

Hassan SM, Byrd JA, Cartwright AL, Bailey CA (2010). Hemolytic and antimicrobial activities differ among saponin-rich extracts from guar, quillaja, yucca, and soybean. Appl. Biochem. Biotechnol. 162:10081017.

Kelly K (2009). History of medicine. New York, Facts on file, 29-50.

Kokate CK (1994). Practical Pharmacognosy, New Delhi: Vallabh Prakashan pp. 107-113.

Levy M, Zehavi U, Naim M, Polacheck I (1989). Isolation, structure determination and antifungal activity of a new native alfalfa root saponin. Carb. Res. 193:115-123.

Lien EJ, Lien LL, Adams JD (2013). Structure-Activity Relationship Analysis of Plant-Derived Compounds. Traditional Chinese Medicine: Scientific Basis for Its Use, 31:11.

Newman DJ, Cragg GM (2012). Natural products as sources of new drugs over the 30 years from 1981 to 2010. J. Nat. Prod. 75:311-335.

Oliveira YLC, Nascimento da Silva LC, Silva AG, Macedo AJ, Araújo JM, Correia MTS, Silva MVD (2012). Antimicrobial Activity and Phytochemical Screening of Buchenavia tetraphylla (Aubl.) RA Howard (Combretaceae: Combretoideae). TSWJ. pp.1-6.

Paphitou NI (2013). Antimicrobial resistance: action to combat the rising microbial challenges. Inter. J. Anti. Agent 425:525-528.

Petrovska BB (2012). Historical review of medicinal plants' usage. Pharm. Rev. 6:1.

Price LB, Stegger M, Hasman H, Aziz M, Larsen J, Andersen PS, Pearson T, Waters AE, Foster JT, Schupp J, Gillece J, Driebe E, Liu CM, Springer B, Zdovc I, Battisti A, Franco A, Żmudzki J, Schwarz S, Butaye $\mathrm{P}$, Jouy E, Pomba C, Porrero MC, Ruimy R, Smith TC, Robinson DA, Weese JS, Arriola CS, Yu F, Laurent F, Keim P, Skov R, Aarestrup FM (2012). Staphylococcus aureus CC398: host adaptation and emergence of methicillin resistance in livestock. mBiol. 3:305-311.

Radulovic NS, Blagojevic PD, Stojanovic-Radic ZZ, Stojanovic NM (2013). Antimicrobial plant metabolites: structural diversity and mechanism of action. Curr. Med. Chem. 20:932-952. 
Saleem M, Nazir M, Ali MS, Hussain H, Lee YS, Riaz N, Jabbar A (2010). Antimicrobial natural products: an update on future antibiotic drug candidates. Nat. Prod. Rep. 27:238-254.

Shimada T, Park BG, Wolf AJ, Brikos C, Goodridge HS, Becker CA, Reyes CN, Miao EA, Aderem A, Götz F, Liu GY, Underhill DM (2010). Staphylococcus aureus evades lysozyme-based peptidoglycan digestion that links phagocytosis, inflammasome activation, and IL-1beta secretion. Cell Host Microbe 7:38-49.

Silva AG, Silva LCN; Macedo CBF; Araujo DRC, Silva JFV, Arruda IR, Araújo JM, Baumvol IJR, Macedo AJ, Correia MTS, Silva MV (2012). Antimicrobial activity of medicinal plants of the Caatinga (semi-arid) vegetation of NE Brazil. Curr. Top. Phytochem. 11:81-94.

Tim CTP, Lamb AJ (2005). Antimicrobial activity of flavonoids. Intern. J. Antimicrob. Agent 26:343-356.

Toutain PL, Bousquet-Melou A (2013). The consequences of generic marketing on antibiotic consumption and the spread of microbial resistance: the need for new antibiotics. J. Vet. Pharm. Ther. 2013:15.
Trentin DS, Giordani RB, Zimmer KR, Silva AG, Silva MS, Correia MTS, Baumvol IJR, Macedo AJ (2011). Potential of medicinal plants from the Brazilian semi-arid region (Caatinga) against Staphylococcus epidermidis planktonic and biofilm lifestyles. J. Ethnopharmacol. 137:327-335.

Trentin DS, Silva DB, Amaral MW, Zimmer KR, Silva MV, Lopes NP, Giordani RB, Macedo AJ (2013). Tannins Possessing Bacteriostatic Effect Impair Pseudomonas aeruginosa Adhesion and Biofilm Formation. PloS one 8:e66257.

Vuuren S,Viljoen A (2011). Plant-Based Antimicrobial Studies Methods and Approaches to Study the Interaction between Natural Products. Plant Med. 77:1168-1182. 